\title{
Social Acceptability Studies of Host Communities of Opada Forest Reserve for Ecotourism Development and Promotion
}

\author{
S. O. Ebiloma, F. A. Sale \\ Department of Forestry and Wildlife, Faculty of Agriculture, Kogi State University, Anyigba, Nigeria \\ Email: ebilomastella@gmail.com
}

How to cite this paper: Ebiloma, S.O. and Sale, F.A. (2017) Social Acceptability Studies of Host Communities of Opada Forest Reserve for Ecotourism Development and Promotion. Open Journal of Social Sciences, 5, 368-383.

https://doi.org/10.4236/jss.2017.55025

Received: February 18, 2017

Accepted: May 24, 2017

Published: May 27, 2017

Copyright ( 92017 by authors and Scientific Research Publishing Inc. This work is licensed under the Creative Commons Attribution International License (CC BY 4.0).

http://creativecommons.org/licenses/by/4.0/

\begin{abstract}
To ensure sustainable flow of benefits from the resources of Opada Forest Reserve (OFR), ecotourism needs to be introduced, which requires understanding the cultural beliefs and the social acceptability of host communities (HC) of the reserve. The objectives of this study were to: harness the opinions and cultural beliefs of the HC of Opada Forest Reserve concerning ecotourism development in OFR. Data collection involved administration of 653 structured questionnaires to $20 \%$ of the population of the $17-\mathrm{HC}$ of OFR. Data were analyzed using descriptive statistics and Chi-square at $\mathrm{p} \leq 0.05$. Results revealed that: Host community respondents (HCR) do not want OFR de-reserved; the desire of most HCR is to participate in the management of OFR (79.5\%); HCR showed willingness to work in the reserve (87.1\%); Presence of conflicts (17.8\%) between HC and Forestry Department (FD) is not significant. Respondents want OFR to be converted to a game reserve (83.2\%). Respondents unequivocally responded $(88 \%)$ that biodiversity conservation is a necessity. Government advised that a game reserve or more desirably, a national park be established in OFR. If $\mathrm{HC}$ hated the idea, $87 \%$ of respondents from 17 different communities will not show interest $(\mathrm{P}=0.43190)$ to work there when established.
\end{abstract}

\section{Keywords}

Kogi State, Opada Forest Reserve, Social Acceptability, Host Community Respondents, Cultural Beliefs, Biodiversity Conservation

\section{Introduction}

Kenya's national parks and game reserves form the pillar of the country's tourism industry. Wildlife viewing and safari tourism are significant generators of 
income and foreign exchange, ensured by the promulgation of national parks in Kenya in the mid- $20^{\text {th }}$ century followed by wildlife conservation initiatives. Government supported policies and programmes that focused on wildlife protection and promotion of safari tourism [1].

Kogi State is one of the 36 states of the Federal Republic of Nigeria. Kogi State stands to gain a lot from wildlife viewing and safari tourism development with its 36 forest reserves (Opada Forest inclusive), rich lush vegetation and its natural formations of hills and rocks. With so many forests possessing natural integrity, there is no single national park, game reserve, wildlife park or zoo in the state even with the current prevalence of indiscriminate utilization of forest resources. Some of the utilization procedures or methods of obtaining some of the forest resources are destructive to biodiversity. The level of poverty in the State is another reason why the resources in Opada Forest Reserve should not be left to the benefits of a few individuals, when they can be judiciously put into use for the benefit of the general public in perpetuity through ecotourism development. National parks, game reserves and zoos are sources of good income for the state and individuals. This income comes in by way of bills paid by tourist for viewing the animals, for buying souvenirs, for accommodation, for transportation, feeding, refreshment and other expenditure within the state by the ecotourists.

The objectives of this study therefore were to:

- To harness the opinions of host communities of Opada Forest Reserve concerning ecotourism development in Opada Forest Reserve.

- To access the traditional beliefs of host communities of Opada Forest Reserve concerning ecotourism development in OFR.

\section{Methodology}

\subsection{Study Area}

Opada Forest Reserve is located in the Eastern part of Kogi State (Figure 1). It lies between latitude $07^{\circ} 48^{\prime} 00.00^{\prime \prime} \mathrm{N}$ to Latitude $07^{\circ} 57^{\prime} 00.00^{\prime \prime} \mathrm{N}$ and Longitude $007^{\circ} 19^{\prime} 00.00^{\prime \prime E}$ to Longitude $07^{\circ} 31^{\prime} 00.00^{\prime \prime} \mathrm{E}$ and was set aside in accordance with section 36 of the forestry ordinance, approved $29^{\text {th }}$ January, 1934.

The forest is watered by Egahi, Iyale, Oju ajoma-egbi, Emae, Inergia and Oje-ajokpa rivers. It is surrounded by seventeen host communities (villages), belonging to three different local government areas (LGA) as follows:

Bassa LGA: -Emae, Ojuwo, Owomo, Ebenehi, Ogbakaka,

Dekina LGA: -Aloko-Oganeinugu, Ajegima, Ajomochaja,

Omala LGA: -Opada, Agabifor, Iyade, Okochuku, Aji-dakwoji, Egbashi, Abegukolo, Agbenema, Ajishekpa, Other important details of Opada Forest Reserve are in Table 1 and transcribed into the current map (Figure 2).

\subsection{Data Collection}

Data collection involved the use of primary and secondary sources of data. 


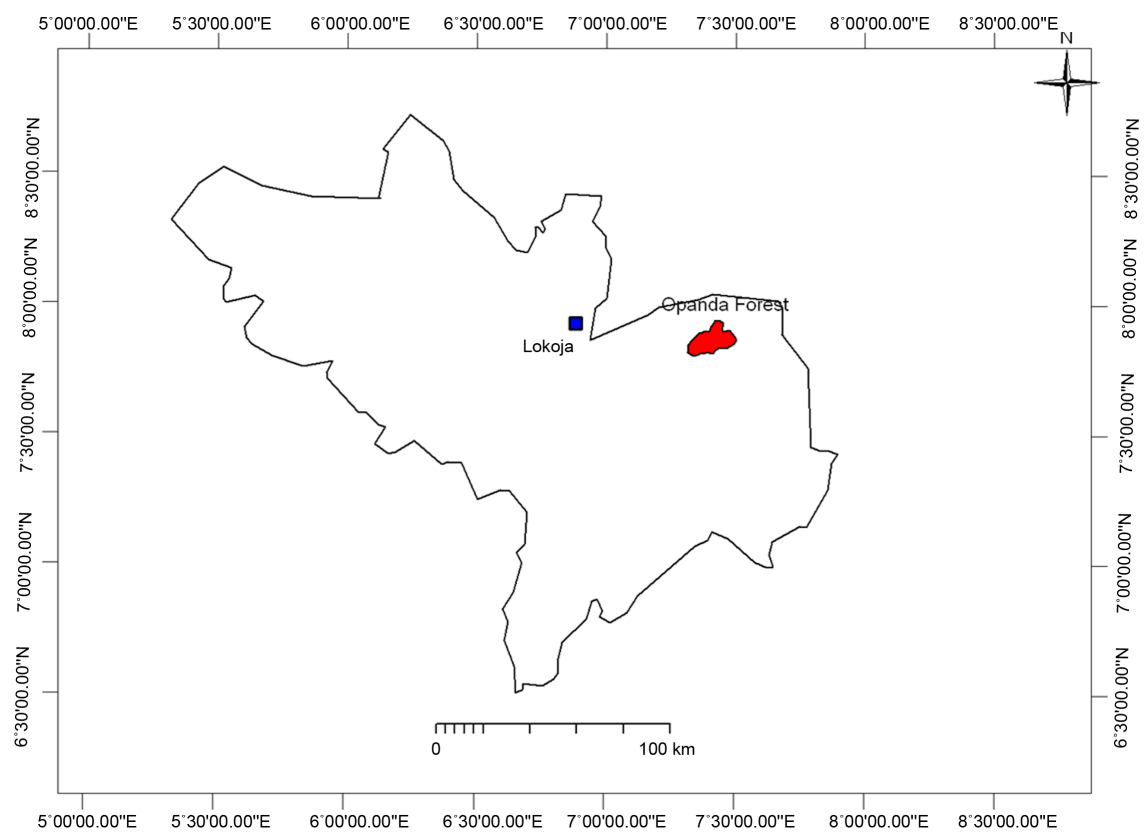

Figure 1. Map of Kogi Sate showing the Location of Opada Forest in Kogi State.

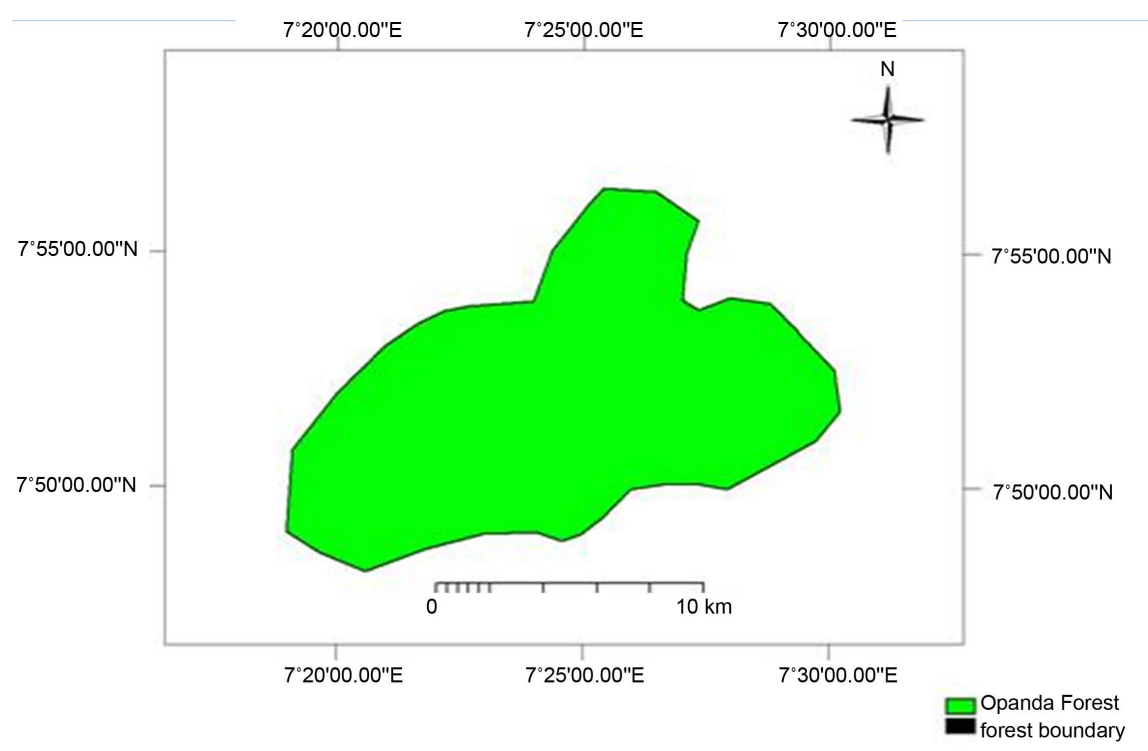

Figure 2. Map of Opada Forest obtained from perimeter GPS Field readings.

Table 1. Opada Forest Reserve, Kogi State.

\begin{tabular}{|c|c|c|c|c|c|c|}
\hline $\begin{array}{c}\text { Name of } \\
\text { forest reserve }\end{array}$ & $\begin{array}{l}\text { Location } \\
\text { (LGA) }\end{array}$ & Extent & $\begin{array}{c}\text { Natural } \\
\text { vegetation type }\end{array}$ & Gazette no & $\begin{array}{c}\text { Management } \\
\text { objective }\end{array}$ & $\begin{array}{l}\text { Major } \\
\text { Threat }\end{array}$ \\
\hline Opada & $\begin{array}{c}\text { Omala } \\
\text { Dekina Bassa }\end{array}$ & $\begin{array}{c}21,523 \mathrm{ha} \\
215.17 \mathrm{~km}^{2}\end{array}$ & $\begin{array}{l}\text { Derived } \\
\text { savanna }\end{array}$ & $\begin{array}{c}\text { No } 58 \text { of } \\
1934\end{array}$ & Production & Man \\
\hline
\end{tabular}

SOURCE: Kogi State Ministry of Agriculture and Natural Resources, Lokoja (2008).

Primary sources of data included oral interviews and administration of two different sets of structured questionnaire, one set to members of Staff of the Department of Forestry and Wildlife, ministry of Agriculture, Headquarters, Loko- 
ja, the Area forestry office, Abejikolo and the second set went to the 17 Host communities of Opada Forest Reserve. The 17-host communities included towns and villages in the immediate vicinity of Opada forest reserve. The team of enumerators included an Agricultural Development Programme (ADP) staff that helped to train the other team members on how to administer questionnaires to the villagers. The sampling technique used is purposive random sampling, this is because the questionnaire were administered to only adults then the adults were randomly selected since all the adults in the population could not be sampled. At the offices of the Ministry of Agriculture and natural resources, Forestry and Wildlife staffs were the ones sampled while at the host communities questionnaires were administered to $20 \%$ of the population, proportionate to size. while secondary sources included review of official records involving the perusal of official documents (files, diagrams, photographs, maps, memos of correspondence with government functionaries, etc.) and information in texts books, journals, conference proceedings and internet which were available and relevant to the study.

\section{Results}

A total of 653 respondents, responded to the questionnaire administered to all the host communities having direct border with the reserve, at the time of this study (Table 2), they were 17, the ones with the largest number of respondents, were Abejukolo (28.9\%) and Aloko-oganeinugu (20.7\%).

It was observed that at least, about $56.5 \%$ of the respondents represented in Table 3 had lived in the host communities continuously for 21 - 95 years; only $14.1 \%$ of them had lived in the host communities for 10 years or less.

Table 2. Percentage of Each Host Communities to the Total Number of Respondents from Host Communities of Opada Forest Reserve.

\begin{tabular}{cccc}
\hline S/N & VARIABLES & FREQUENCY & PERCENTAGE \\
\hline 1 & Abejukolo & 182 & 28.87 \\
2 & Egbachi & 16 & 2.45 \\
3 & Ogbakaka & 5 & 0.75 \\
4 & Ajidakwoji & 4 & 0.61 \\
5 & Agabifor & 9 & 1.38 \\
6 & Emae & 11 & 1.68 \\
7 & Ebenehi & 10 & 1.53 \\
8 & Ajomocheja & 35 & 5.36 \\
9 & Opada & 16 & 2.45 \\
10 & Ajishekpa & 21 & 3.22 \\
11 & Ajejima & 15 & 2.30 \\
12 & Okochuku & 15 & 2.20 \\
13 & Aloko-Oganainugu & 135 & 20.67 \\
14 & Agbenema & 57 & 8.72 \\
15 & Ojuwo & 52 & 7.96 \\
16 & Iyade & 40 & 6.13 \\
17 & Owomo & 30 & 4.59 \\
& Total & 653 & 100 \\
\hline
\end{tabular}


Table 3. Extent to Which Information from Opada Host Communities Can Be Trusted.

\begin{tabular}{cccc}
\hline VARIABLES & OPTIONS & $\begin{array}{c}\text { FREQUENCY } \\
\text { DISTRIBUTION }\end{array}$ & PERCENTAGE \\
\hline $1-10$ years & 92 & 14.09 \\
$11-20$ years & 154 & 23.57 \\
$21-30$ years & 127 & 19.45 \\
& $31-40$ years & 177 & 27.10 \\
& $41-50$ years & 53 & 8.1 \\
Length of time lived in & $51-60$ years & 6 & 0.91 \\
host community & $61-70$ years & 2 & 0.30 \\
& $71-80$ years & 1 & 0.15 \\
& $81-90$ years & 1 & 0.15 \\
& $91-95$ years & 1 & 0.15 \\
& No response & 39 & 5.97 \\
& Total & 653 & 100.00
\end{tabular}

\subsection{Demographic and Social Characteristics of Host Communities of Opada Forest Reserve Respondents}

Host communities are occupied by people of different religions living in peace, throughout this study no tension of any kind was observed in the host communities; they are peace lovers who go about their daily duties without grudges. Some of the team members for this research who were temporarily accommodated in one of the host communities were accorded hospitality in all its ramifications and never had course to complain of ill treatment till they left their location.

It was observed that most of the respondents were males (80.40\%) and most of them were natives of the $\mathrm{HC}(84.38 \%)$, however, $84.53 \%$ of the respondents did not indicate their tribes (Table 4).

Many religions are represented in the host communities, but $56.81 \%$ of the respondents were Christians.

Of the 653 host community respondents, $95.71 \%$ of them belonged to one association or the other, some of them belonged to as many as 10 associations (Table 4), indicating high affinity for Friendship and a good indicator for ecotourism.

A good percentage (63.2\%) of the host community respondents had secondary and tertiary education, only $12.7 \%$ had no formal education (Table 5).

Major occupation question (Table 5) revealed that of the 653 respondents, people are farmers $(37.2 \%)$, self civil servants (11.3\%), traders (17.2\%) etc.

The length of time these people have been engage in these various occupations has been from 1 to 65years (Table 5).

\subsection{Acceptability of Opada Forest Reserve as Game Reserve by Host Communities}

Technically, to de-reserve a forest reserve is to lower its status or removal of government conservation interest while to upgrade it is to improve on its status, thus it becomes a game reserve or a national park. Due to poverty coupled with 
Table 4. Demographic and social characteristics of host communities of Opada forest reserve respondents.

\begin{tabular}{|c|c|c|c|c|}
\hline $\mathrm{S} / \mathrm{N}$ & VARIABLES & OPTIONS & $\begin{array}{c}\text { FREQUENCY } \\
\text { DISTRIBUTION }\end{array}$ & PERCENTAGE \% \\
\hline \multirow{4}{*}{1} & \multirow{4}{*}{$\begin{array}{c}\text { Sex Of } \\
\text { Respondents }\end{array}$} & Male & 525 & 80.40 \\
\hline & & Female & 111 & 17.00 \\
\hline & & No response & 17 & 2.60 \\
\hline & & Total & 653 & 100. \\
\hline \multirow{4}{*}{2} & \multirow{4}{*}{$\begin{array}{l}\text { Native of host } \\
\text { community }\end{array}$} & Yes & 551 & 84.38 \\
\hline & & No & 88 & 13.48 \\
\hline & & No response & 14 & 2.14 \\
\hline & & Total & 653 & 100. \\
\hline \multirow{7}{*}{3} & \multirow{7}{*}{$\begin{array}{l}\text { Tribe of } \\
\text { respondents }\end{array}$} & Igala & 48 & 7.35 \\
\hline & & Yoruba & 4 & 0.61 \\
\hline & & Ibo & 9 & 1.38 \\
\hline & & Hausa & 2 & 0.31 \\
\hline & & Others & 38 & 5.82 \\
\hline & & No response & 552 & 84.53 \\
\hline & & Total & 653 & 100 \\
\hline \multirow{7}{*}{4} & \multirow{7}{*}{ Religion } & Atheist & 6 & 0.92 \\
\hline & & Christian & 371 & 56.81 \\
\hline & & Muslim & 238 & 36.44 \\
\hline & & Traditional religion & 024 & 3.68 \\
\hline & & Others & 0 & 0 \\
\hline & & No response & 14 & 2.14 \\
\hline & & Total & 653 & 100 \\
\hline \multirow{11}{*}{5} & \multirow{11}{*}{$\begin{array}{l}\text { Number of } \\
\text { association } \\
\text { respondents } \\
\text { belong to }\end{array}$} & None & 78 & 12.10 \\
\hline & & 1 & 254 & 38.90 \\
\hline & & 2 & 208 & 31.85 \\
\hline & & 3 & 57 & 8.73 \\
\hline & & 4 & 12 & 1.84 \\
\hline & & 5 & 6 & 0.92 \\
\hline & & 6 & 5 & 0.77 \\
\hline & & 7 & 2 & 0.31 \\
\hline & & 10 & 2 & 0.31 \\
\hline & & No response & 28 & 4.29 \\
\hline & & Total & 653 & 100 \\
\hline \multirow{11}{*}{6} & \multirow{11}{*}{$\begin{array}{l}\text { Age bracket of } \\
\text { respondents }\end{array}$} & Under 20 years old & 81 & 12.40 \\
\hline & & 21-30 years old & 153 & 23.44 \\
\hline & & $31-40$ years old & 262 & 40.13 \\
\hline & & $41-50$ years old & 98 & 15.00 \\
\hline & & $51-60$ years old & 34 & 5.21 \\
\hline & & $61-70$ years old & 7 & 1.06 \\
\hline & & 71 - 80 years old & 2 & 0.3 \\
\hline & & 81 - 90 years old & 3 & 0.46 \\
\hline & & 91 - 100 years old & 1 & 0.15 \\
\hline & & No response & 12 & 1.83 \\
\hline & & Total & 653 & 100 \\
\hline
\end{tabular}




\section{Continued}

\begin{tabular}{|c|c|c|c|c|}
\hline \multirow{6}{*}{7} & \multirow{6}{*}{ Marital status } & Single & 189 & 28.94 \\
\hline & & Married & 413 & 63.25 \\
\hline & & Widowed & 7 & 1.07 \\
\hline & & Divorced & 10 & 1.53 \\
\hline & & No response & 34 & 5.21 \\
\hline & & Total & 653 & 100 \\
\hline \multirow{10}{*}{8} & \multirow{10}{*}{ Number of wives } & No wife & 2 & 0.31 \\
\hline & & 1 & 252 & 38.90 \\
\hline & & 2 & 89 & 13.63 \\
\hline & & 3 & 24 & 3.68 \\
\hline & & 4 & 8 & 1.23 \\
\hline & & 5 & 1 & 0.15 \\
\hline & & 6 & 1 & 0.15 \\
\hline & & 8 & 1 & 0.15 \\
\hline & & No response & 273 & 41.81 \\
\hline & & Total & 653 & 100 \\
\hline \multirow{24}{*}{9} & \multirow{24}{*}{$\begin{array}{l}\text { Number of } \\
\text { children }\end{array}$} & None & 3 & 0.46 \\
\hline & & 1 & 23 & 3.52 \\
\hline & & 2 & 60 & 9.19 \\
\hline & & 3 & 83 & 12.71 \\
\hline & & 4 & 86 & 13.17 \\
\hline & & 5 & 40 & 6.13 \\
\hline & & 6 & 50 & 7.66 \\
\hline & & 7 & 24 & 3.68 \\
\hline & & 8 & 22 & 3.67 \\
\hline & & 9 & 17 & 2.60 \\
\hline & & 10 & 7 & 1.07 \\
\hline & & 11 & 8 & 1.23 \\
\hline & & 12 & 7 & 1.07 \\
\hline & & 13 & 7 & 1.07 \\
\hline & & 14 & 4 & 0.61 \\
\hline & & 15 & 3 & 0.46 \\
\hline & & 16 & 2 & 0.31 \\
\hline & & 17 & 1 & 0.15 \\
\hline & & 18 & 1 & 0.15 \\
\hline & & 20 & 1 & 0.15 \\
\hline & & 23 & 1 & 0.15 \\
\hline & & 31 & 1 & 0.15 \\
\hline & & No response & 202 & 30.93 \\
\hline & & Total & 653 & 100 \\
\hline \multirow{10}{*}{10} & \multirow{10}{*}{$\begin{array}{l}\text { Number of } \\
\text { dependants }\end{array}$} & $0-4$ & 180 & 27.57 \\
\hline & & $5-9$ & 184 & 28.17 \\
\hline & & $10-15$ & 93 & 11.25 \\
\hline & & $16-20$ & 18 & 2.76 \\
\hline & & $21-25$ & 4 & 0.61 \\
\hline & & $26-30$ & 0 & 0 \\
\hline & & $31-35$ & 1 & 0.15 \\
\hline & & 38 & 2 & 0.31 \\
\hline & & No response & 171 & 26.17 \\
\hline & & Total & 653 & 100 \\
\hline
\end{tabular}


other pressing needs, some individuals within and around the host communities of this reserve are agitating for more opportunities for greater utilization of the reserve by them, not taking into cognizance that this can lead to totally removing the status of reservation presently preserving the reserve.

To access the extent of acceptability of host communities of Opada Forest Reserve as Game Reserve (Table 6), Host communities (58.5\%) said the reserve should not be de-reserved.

In the event that it is de-reserved some want land (15.9\%), part of the forest (9.8\%), some insisted they want nothing to do with the forest land (33.5\%, Table $6)$.

Table 5. Level of education and occupational activities of host communities of Opada Forest Reserve.

\begin{tabular}{|c|c|c|c|c|}
\hline $\mathrm{S} / \mathrm{N}$ & VARIABLES & OPTIONS & $\begin{array}{c}\text { FREQUENCY } \\
\text { DISTRIBUTION }\end{array}$ & PERCENTAGE \\
\hline \multirow{6}{*}{1} & \multirow{6}{*}{ Level of education } & None & 82 & 12.56 \\
\hline & & Primary & 37 & 5.67 \\
\hline & & Secondary & 320 & 49.00 \\
\hline & & Tertiary & 93 & 14.24 \\
\hline & & No response & 121 & 18.53 \\
\hline & & Total & 653 & 100 \\
\hline \multirow{16}{*}{2} & \multirow{16}{*}{ Major occupation } & Farming & 243 & 37.21 \\
\hline & & Self employed & 5 & 0.70 \\
\hline & & Civil servant & 74 & 11.33 \\
\hline & & Trading & 112 & 17.15 \\
\hline & & Hunting & 14 & 2.14 \\
\hline & & Private employee & 34 & 5.21 \\
\hline & & Student & 94 & 14.39 \\
\hline & & Farming and hunting & 4 & 0.61 \\
\hline & & Farming and civil servant & 4 & 0.61 \\
\hline & & Trading and private employee & 1 & 0.15 \\
\hline & & Private employee and farming & 2 & 0.31 \\
\hline & & Trading and student & 2 & 0.31 \\
\hline & & Civil servant and trading & 3 & 0.46 \\
\hline & & Trading and farming & 2 & 0.30 \\
\hline & & No response & 59 & 9.04 \\
\hline & & Total & 653 & 100 \\
\hline \multirow{9}{*}{3} & \multirow{9}{*}{$\begin{array}{l}\text { Length of time in } \\
\text { the above } \\
\text { occupation/job }\end{array}$} & $1-10$ & 168 & 25.59 \\
\hline & & $11-20$ & 198 & 29.55 \\
\hline & & $21-30$ & 103 & 15.78 \\
\hline & & $31-40$ & 30 & 4.60 \\
\hline & & $41-50$ & 7 & 1.07 \\
\hline & & $51-60$ & 2 & 3.00 \\
\hline & & $61-65$ & 1 & 0.15 \\
\hline & & No response & 149 & 22.82 \\
\hline & & Total & 653 & 100 \\
\hline
\end{tabular}




\section{Continued}

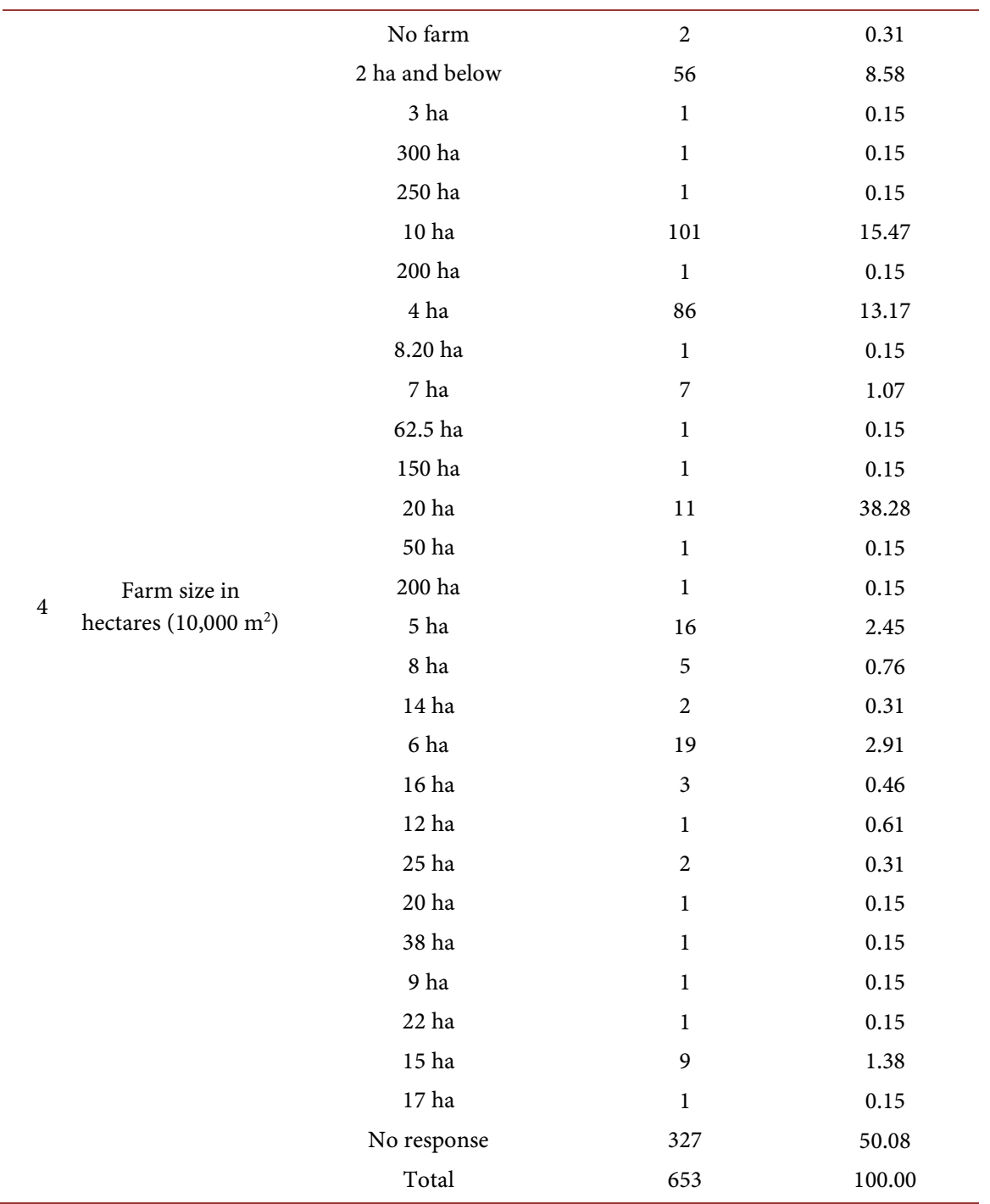

Respondents that showed no response / interest in obtaining part of forest increased from $40.1 \%$ to $51.3 \%$ in addition to those who said nothing buttressing the conclusion that host communities are interested in the conservation of the forest reserve (Table 6).

The use to which the portion of forest received will be put showed that some will farm with theirs (19.8\% of them), maintain a forest (27.0\%), some still claimed they will do nothing with the land they will receive (1.7\%), while 51.3\% signified no interest (Table 6).

Whether the forest will survive if individuals owned the forest, $68.3 \%$ claimed it will not survive (Table 6).

To be involved in the management of Opada Forest Reserve is the desire of most host community respondents (79.5\%), some are however not interested (12.6\%, Table 6). The response of the respondents as presented on this table shows that the respondents are interested in contributing towards the decisions taken concerning their common resource; this is the current trend in the 
Table 6. Acceptability of Opada Forest Reserve as Game Reserve by Host Communities.

\begin{tabular}{|c|c|c|c|c|}
\hline $\mathrm{S} / \mathrm{N}$ & VARIABLES & OPTIONS & \multicolumn{2}{|c|}{$\begin{array}{l}\text { FRQUENCY } \\
\text { DISTRIBUTION }\end{array}$} \\
\hline \multirow{4}{*}{1} & \multirow{4}{*}{$\begin{array}{c}\text { Whether } \\
\text { government should } \\
\text { de-reserve } \\
\text { Opada Forest Reserve }\end{array}$} & Yes & 169 & 25.88 \\
\hline & & No & 382 & 58.49 \\
\hline & & No response & 102 & 15.62 \\
\hline & & Total & 653 & 100.00 \\
\hline \multirow{7}{*}{2} & \multirow{7}{*}{$\begin{array}{l}\text { Gain from } \\
\text { de-reserving the } \\
\text { forest }\end{array}$} & Land & 104 & 15.93 \\
\hline & & Part of the forest & 64 & 9.80 \\
\hline & & Nothing & 219 & 33.54 \\
\hline & & Others & 3 & 0.46 \\
\hline & & Land and part of forest & 1 & 0.15 \\
\hline & & No response & 262 & 40.12 \\
\hline & & Total & 653 & 100.00 \\
\hline \multirow{6}{*}{3} & \multirow{6}{*}{$\begin{array}{c}\text { Usefulness of portion } \\
\text { of forest received if } \\
\text { de-reserve }\end{array}$} & Farm & 129 & 19.75 \\
\hline & & Maintaining a forest & 176 & 26.95 \\
\hline & & Nothing & 11 & 1.68 \\
\hline & & Others & 2 & 0.31 \\
\hline & & No response & 335 & 51.30 \\
\hline & & Total & 653 & 100.00 \\
\hline \multirow{4}{*}{4} & \multirow{4}{*}{$\begin{array}{c}\text { Whether forest will } \\
\text { survive if individuals } \\
\text { own it }\end{array}$} & Yes & 170 & 26.03 \\
\hline & & No & 446 & 68.30 \\
\hline & & No response & 37 & 5.67 \\
\hline & & Total & 653 & 100.00 \\
\hline \multirow{4}{*}{5} & \multirow{4}{*}{$\begin{array}{l}\text { To be involved in the } \\
\text { management of } \\
\text { Opada forest reserve }\end{array}$} & Yes & 519 & 79.48 \\
\hline & & No & 82 & 12.56 \\
\hline & & No response & 52 & 7.97 \\
\hline & & Total & 653 & 100.00 \\
\hline \multirow{5}{*}{6} & \multirow{5}{*}{$\begin{array}{c}\text { How host } \\
\text { communities } \\
\text { intend to help } \\
\text { management }\end{array}$} & Report illegal activities & 313 & 47.93 \\
\hline & & Prevent illegal activities & 207 & 31.70 \\
\hline & & Nothing & 2 & 0.31 \\
\hline & & No response & 131 & 20.06 \\
\hline & & Total & 653 & 100.00 \\
\hline \multirow{4}{*}{7} & \multirow{4}{*}{$\begin{array}{l}\text { Knowledge of the } \\
\text { meaning of game } \\
\text { reserve }\end{array}$} & Yes & 543 & 83.15 \\
\hline & & No & 72 & 11.03 \\
\hline & & No response & 38 & 5.82 \\
\hline & & Total & 653 & 100.00 \\
\hline \multirow{4}{*}{8} & \multirow{4}{*}{$\begin{array}{l}\text { Conversion of forest } \\
\text { to game reserve }\end{array}$} & Yes & 557 & 85.30 \\
\hline & & No & 47 & 7.2 \\
\hline & & No response & 49 & 7.50 \\
\hline & & Total & 653 & 100.00 \\
\hline
\end{tabular}




\begin{tabular}{|c|c|c|c|c|}
\hline \multirow{13}{*}{9} & \multirow{13}{*}{$\begin{array}{l}\text { Why the forest } \\
\text { should be converted } \\
\text { to a game reserve }\end{array}$} & Employment & 135 & 20.67 \\
\hline & & Revenue generation & 83 & 12.71 \\
\hline & & Entertainment & 6 & 0.92 \\
\hline & & Development & 144 & 22.05 \\
\hline & & Nothing to gain & 10 & 1.53 \\
\hline & & Honorarium & 16 & 2.45 \\
\hline & & Tourism & 32 & 4.90 \\
\hline & & Food & 5 & 0.77 \\
\hline & & Social amenities & 55 & 8.42 \\
\hline & & Employment and honorarium & 2 & 0.30 \\
\hline & & Revenue generation and entertainment & 1 & 0.15 \\
\hline & & No response & 164 & 25.11 \\
\hline & & Total & 653 & 100.00 \\
\hline \multirow{4}{*}{10} & \multirow{4}{*}{$\begin{array}{l}\text { Conflict between host } \\
\text { communities and the } \\
\text { staff of Department } \\
\text { of forestry }\end{array}$} & Yes & 129 & 19.75 \\
\hline & & No & 450 & 68.91 \\
\hline & & No response & 74 & 11.33 \\
\hline & & Total & 653 & 100.00 \\
\hline \multirow{4}{*}{11} & \multirow{4}{*}{$\begin{array}{c}\text { Whether they are } \\
\text { interested in tourist } \\
\text { visits to Opada forest } \\
\text { reserve }\end{array}$} & Yes & 586 & 89.74 \\
\hline & & No & 8 & 1.23 \\
\hline & & No response & 59 & 9.04 \\
\hline & & Total & 653 & 100.00 \\
\hline \multirow{4}{*}{12} & \multirow{4}{*}{$\begin{array}{l}\text { Whether they will like } \\
\text { to work at the reserve } \\
\text { when tourists come }\end{array}$} & Yes & 569 & 87.14 \\
\hline & & No & 14 & 2.14 \\
\hline & & No response & 70 & 10.72 \\
\hline & & Total & 653 & 100.00 \\
\hline
\end{tabular}

management of ecotourism resources. Asked, how they intend to help management, $47.9 \%$ said they will report illegal activities, $31.7 \%$ will prevent illegal activities. The respondents who said they are willing to help management are $79.6 \%$ of 653 (Table 6). Tourism will thrive in a place where the intention of the people to help management to succeed is top on their scale of preference.

The host community respondents showed high level of interest in game reserve $(83.2 \%)$. They want Opada Forest Reserve to be converted to a game reserve (85.3\%) (Table 6).

Reasons why Opada forest should be converted to a game reserve according to the respondents are especially employment (20.7\%), revenue generation (12.7\%), infrastructural development (22.5\%), honorarium (2.45\%), social amenities (8.4\%, Table 6) etc.

\subsection{Cultural Belief of the Host Communities}

There are parts of the forest people should not enter (54.4\%), because of the traditional beliefs of some of the people (Table 7), but $17.8 \%$ said there is no part of 
Table 7. Cultural Believes of Host Communities As It Pertains to Opada Forest Reserve.

\begin{tabular}{|c|c|c|c|c|}
\hline $\mathrm{S} / \mathrm{N}$ & VARIABLE & OPTIONS & $\begin{array}{l}\text { FREQUENCY } \\
\text { DISTRIBUTION }\end{array}$ & PERCENTAGE \\
\hline \multirow{4}{*}{1} & \multirow{4}{*}{$\begin{array}{l}\text { Asked if there } \\
\text { is part of } \\
\text { forest people } \\
\text { should not go }\end{array}$} & Yes & 355 & 54.36 \\
\hline & & No & 116 & 17.76 \\
\hline & & No response & 182 & 27.87 \\
\hline & & Total & 653 & 100.00 \\
\hline \multirow{10}{*}{2} & \multirow{10}{*}{$\begin{array}{l}\text { Which people } \\
\text { should not go there }\end{array}$} & Men & 42 & 6.43 \\
\hline & & Women & 48 & 7.35 \\
\hline & & Visitors & 73 & 11.18 \\
\hline & & Everyone & 76 & 11.64 \\
\hline & & Non-forest staff & 5 & 0.77 \\
\hline & & Hunters & 2 & 0.31 \\
\hline & & Women and visitors & 23 & 0.15 \\
\hline & & Men and women & 156 & 23.88 \\
\hline & & No response & 228 & 34.92 \\
\hline & & Total & 653 & 100.00 \\
\hline
\end{tabular}

the forest that people are prohibited from. Ajiokpa and Odo are the prohibited areas as deduced from the study. Both men and women should not venture into prohibited areas (Table 7), but $34.9 \%$ of the respondents did not answer the question. This is not a problem, tourists are usually accompanied during game or park viewing and tour guards are usually members of host communities. They were asked how new arrivals to the communities know of the prohibited areas, responses included; town criers, orientation by villagers, occasional warnings to all villagers, through victims. Responses to the issue of what happens to defaulters included; punishment, attacks from wild animals, bad omen, nothing will happen. Remedy for defaulters include; sacrifice to the gods, to prevent trespassing, the people requested the fencing of the place by the government (Personal communication).

\section{Discussion}

\subsection{Host Communities}

Length of stay in the host communities is an indication of the confidence with which the information gathered from the respondents can be accepted. Someone that has stayed long in a place has more firsthand knowledge and experience of that place. The longer one has stayed in a place, the shorter the chain of indigenous information the person has and so more original. One that has not stayed for long passes watered down information because their knowledge and communications are verbal and undocumented.

Most of these people are not gainfully employed and are living in close to poverty conditions. A game reserve or national park as the case may be will mop a good number of them out of the unemployment market as ecotourism's idealistic goal is actually to improve the world through responsible travel according to Jessica [2]. If a good percentage of those living in the host communities of Opa- 
da Forest Reserve are benefiting remuneration from tourism and the other percentage from one service or the other, their families, relatives and friends will also benefit, this multiplier effect will go a long way in ensuring that these people make efforts to ensure the place remain open to tourists forever, thus ensuring conservation, since conservation is a purpose for ecotourism as agreed to by Medina [3].

The fact that up to $73.7 \%$ of the respondents, are not interested in having any part of the reserve for themselves means that they want the forest to remain under the control of government, because they believe once it belongs to individuals, access to it by the generality of the people ceases. Instead of leaving it to sure destruction, it should be put into profitable ventures that will ensure its survival through time and be enjoyed by all.

Opada Forest Reserve is a natural forest, it was to be developed into a wildlife park by the Federal Wildlife Department 1998, there was even a proposal for fencing and building of chalets inside the reserve then, a monitoring team even visited with respect to that intention but funds were never released to that effect. The reserve has faced serious illegal exploitations but there has never been any form of enrichment planting or restocking with plants or animals however the external boundaries were retraced in 1997-1999 using unconventional methods of allowing members of host communities to fell the trees along the forest boundaries (oral interview).

\subsection{Reasons Why Opada Forest Should Be Converted to a Game Reserve or National Park}

In the event that Opada Forest Reserve is upgraded to a game reserve or National park, the beneficiaries are represented by 653 respondents drawn from the seventeen host communities having boundaries with the reserve and passing to the world the mind of the people. This venture will help depopulate the unemployment market and reduce the negative tendencies like armed robbery, sexual promiscuity especially among the youths, over population, poverty and its associated vices. It will result in the reduction of rural urban drift, because with the development of ecotourism, facilities will be put in place to sustain tourist inflow, which will benefit host communities such as good roads. In the event that the place is linked to the national grid for electricity supply, it will definitely pass through some communities, network providers will be attracted to establish their masts to increase their patronage around the park, host communities will also benefit through employment, small scale businesses, Craftspeople, innkeepers and restaurateurs etc. [2], thus encouraging local people to continue to live in their communities, thereby reducing urban rural drift. From the fore going, host communities of Opada Forest Reserve and biodiversity will benefit more from a national park than a game reserve and from a game reserve than a forest reserve.

\subsection{Route to Opada Forest Reserve}

The most developed town around Opada Forest Reserve is Abejukolo, the local 
Table 8. Taboo Sections of Opada Forest Reserve.

\begin{tabular}{cccc}
\hline Pearson chi-square & Chi-square & Df & P \\
\hline 43.9439 & $\mathrm{df}=16$ & $\mathrm{P}=0.00020$ \\
\hline
\end{tabular}

$\mathrm{H}_{0}=$ Respondent's view as to whether there are parts of the forest people are forbidden or not does not depend on communities $H_{a}=$ Respondent's view as to whether there are parts of the forest people are forbidden or not depend on communities Respondent's view as to whether there are parts of the forest people are forbidden or not significantly depend on communities. This is because not all the communities adhere to the idea of restriction in any part of the forest as shown in Table 8.

Table 9. Category of People Forbidden From Taboo Sections of Opada Forest Reserve.

\begin{tabular}{cccc}
\hline Pearson chi-square & Chi-square & Df & P \\
\hline 509.4287 & $\mathrm{df}=128$ & $\mathrm{P}=0.0000$ \\
\hline
\end{tabular}

$\mathrm{H}_{0}=$ Category of people forbidden from the forest does not depend on communities. $\mathrm{H}_{\mathrm{a}}=$ Category of people forbidden from the forest significantly depend on communities. The result of Table 9 showed that categories of people forbidden from the forest significantly depend on communities.

Table 10. Willingness of Host Community to Work at the Reserve When Established.

\begin{tabular}{cccc}
\hline Pearson chi-square & Chi-square & Df & $P$ \\
\hline 16.30498 & $\mathrm{df}=16$ & $\mathrm{P}=0.43190$ \\
\hline
\end{tabular}

$\mathrm{H}_{0}=$ Respondents' willingness to work in the reserve when tourists begin to come does not depend on communities. $\mathrm{H}_{\mathrm{a}}$ = Respondents' willingness to work in the reserve when tourists begin to come depend on communities. Respondents' willingness to work in the reserve when tourists begin to come does not significantly depend on communities as shown in Table 10.

Table 11. Interest of Host Communities in Playing Host to Tourists.

\begin{tabular}{cccc}
\hline Pearson chi-square & Chi-square & Df & $P$ \\
\hline 7.384397 & $\mathrm{df}=16$ & $\mathrm{P}=0.96512$ \\
\hline
\end{tabular}

$\mathrm{H}_{0}=$ Respondents interest in tourist visit does not depend on communities. $\mathrm{H}_{\mathrm{a}}=$ Respondents interest in tourist visit depend on communities. Respondents' interest in tourists visit does not significantly depend on communities as shown in Table 11.

Table 12. Test of Conflicts between Host Communities and Forestry Department Staff.

\begin{tabular}{cccc}
\hline Pearson chi-square & Chi-square & Df & $P$ \\
\hline 160.4524 & $\mathrm{df}=16$ & $\mathrm{P}=0.00000$ \\
\hline
\end{tabular}

$\mathrm{H}_{0}=$ Presence or absence of conflicts does not depend on communities. $\mathrm{H}_{\mathrm{a}}=$ Presence or absence of conflicts depend on communities. Presence or absence of conflicts between host communities and Forestry Department does not significantly depend on communities as shown in Table 12.

government head quarters of Omala Local Government Area, one of the three local government areas having boundaries with Opada Forest Reserve, the office of the Area Forestry Officer overseeing Opada Forest Reserve is also located here. It has good road roads network, it is connected to Lokoja the Kogi State capital with good roads, and Lokoja is in turn linked with Lagos and Abuja with good roads network. Abejukolo currently boasts of three standard, well furnished hotels and twelve restaurants. The hotels are; Omala Hotel (14-rooms), Omaji Hotel (22-rooms) and Abdul-ashier Hotel (9-rooms) in addition to nu- 
merous eateries. There is a big and booming smoked fish market called Bagana Fish Market, 13.68 km (8.5 miles) from Abejukolo.

Distances to Opada Forest Reserve are:

+ Lagos to Abuja-521 km (324 miles) $281 \mathrm{~nm} \nearrow \mathrm{NE}[4]$

+ Lagos to Lokoja-535 km and can be crossed in about 7 hours 36 mins Distance calculator

Abuja to Lokoja - $202 \mathrm{Km}$ travelled in 1 day [5].

Lokoja to Abejukolo-152 miles

\section{Conclusion}

It is worthy to note that 653 respondents in 17 remote, interior villages who responded to the questionnaire under consideration unequivocally responded (88\%) that biodiversity conservation is a necessity, and they do not want Opada forest de-reserved because they fear the forest will cease to exist if that happens.

Host communities want Opada forest to become a game reserve or a national park. They are interested in playing host to tourist and harnessing other benefits that can support their livelihood. The government is expected to be interested in a venture that the host communities are as highly interested as the conservation of Opada Forest reserve. It is strongly advised that a game reserve or more desirably, a national park be established quickly. The level of interest these people have shown will readily embrace ecotourism efforts. If they hated the idea, $87 \%$ of the respondents from 17 different communities will not show interest $(\mathrm{P}=$ 0.43190 ) to work there when it is established.

\section{Recommendations}

The Kogi State Government should consider positively the conversion of one of the 36 forest reserves (Opada Forest Reserve) in the state into a game reserve or appeal to the Federal Government to upgrade Opada Forest Reserve to a national park. Either way, the people stand to gain by way of biodiversity conservation, job creation, revenue generation by the government and the locals.

Pressure from conservationist and international public opinion is strongly requested to prevail on the government of Kogi State to establish a game reserve in place of Opada forest reserve so as to ensure sustainability of the reserve for posterity in perpetuity.

\section{References}

[1] John, S.A., Shem, M. and Blanca, A.C. (2011) Wildlife Conservation, Safari Tourism and the Role of Tourism Certification in Kenya: A Postcolonial Critique. Tourism Recreation Research, 36, 281-291.

[2] Jessica, B. (2012) Green Living.

[3] Medina, J.K. (2012) The Uses of Ecotourism.

[4] Coordinated Universal Time (2015) Time and Date.

http://legacysite3.timeanddate.com/worldclock/distances.html?n = 125\&continent = africa 
[5] softUsvista Inc. (2012) Distances from Abuja to Lokoja. http://www.distancesfrom.com/ng/distance-from-Abuja-to-Lokoja/DistanceHistory 1938163.aspx

Submit or recommend next manuscript to SCIRP and we will provide best service for you:

Accepting pre-submission inquiries through Email, Facebook, LinkedIn, Twitter, etc. A wide selection of journals (inclusive of 9 subjects, more than 200 journals)

Providing 24-hour high-quality service

User-friendly online submission system

Fair and swift peer-review system

Efficient typesetting and proofreading procedure

Display of the result of downloads and visits, as well as the number of cited articles Maximum dissemination of your research work

Submit your manuscript at: http://papersubmission.scirp.org/

Or contact jss@scirp.org 